\title{
SPECTROSCOPIC AND ELECTROCHEMICAL PROPERTIES OF A SERIES OF SUBSTITUTED POLYPYRIDINE Co(II)/Co(III) COUPLES AND THEIR POTENTIALITY AS MEDIATORS FOR SOLAR CELLS.
}

\author{
FRANCISCO GAJARDO* AND BÁRBARA LOEB
}

\author{
Facultad de Química, Pontificia Universidad Católica de Chile, Casilla 306, Santiago, Chile
}

(Received: November 3, 2010 - Accepted: May 5, 2011)

\begin{abstract}
This paper reports the synthesis, characterization and spectroscopic and electrochemical study of a series of polypyridine Co(II) and Co(III) complexes. The effect on the redox potential of the presence of donor or acceptor substituents on the ligand, as well as the effect of an increased ligand aromaticity, was analyzed. Specifically, complexes of $\left[\mathrm{Co}(\mathrm{L}-\mathrm{L})_{3}\right]^{\mathrm{n}}$ type were prepared, with $\mathrm{n}=2,3$, and $\mathrm{L}-\mathrm{L}=1,10$-phenanthroline (phen), 5-amino-1,10'-phenanthroline (phen-NH ), $^{\prime}$ 3,4,7,8-tatramethyl phenantroline (phen-4Me), pyrazino[2,3-f][1,10]phenanthroline (ppl), 2-methylpyrazino[2,3-f][1,10]phenanthroline (ppl-Me), dipyrido[3,2$\left.a: 2^{\prime}, 3^{\prime}-c\right]$ phenazine (dppz), 7-methyldipyrido[3,2-a:2',3'-c]phenazine (dppz-Me) and 7-aminodipyrido[3,2-a:2',3'-c]phenazine (dppz- $\left.\mathrm{NH}_{2}\right)$. The results of this study open the possibility to have a battery of potential mediators for photoelectrochemical solar cells. Ultimately, the election of a determined couple as mediator will depend mainly on the electronic properties of the specific dye in a given cell.
\end{abstract}

Keywords: Cobalt polypyridine complexes, redox potential, substituent effect.

\section{INTRODUCTION}

Solar radiation is an inexhaustible energy source and probably one of the best candidates to be used in devices in order to cover the increasing world energy demands. While efficient solar energy conversion has been around for decades, the cost of electricity production from solar conversion is still higher than from conventional coal-based sources. ${ }^{1}$ Photoelectrochemical cells based on dye sensitized semiconductor photoanodes have been mentioned for a long time in literature, ${ }^{2}$ but it was only on 1991, after O'Regan and Graetzel's report of a photovoltaic device based on the sensitization of nanoparticulated $\mathrm{TiO}_{2}$ electrodes, ${ }^{3}$ that this possibility came to be intensely considered as an alternative energy source. The functioning of the frequently called "Graetzel cells" basically consists of light absorption by a chromophore attached to the surface of a $\mathrm{TiO}_{2}$ nanoparticulated photoanode, followed by the injection of an electron into the $\mathrm{TiO}_{2}$ conduction band by the excited dye. This electron, which is the source of the photocurrent, is driven by an external circuit to the counter electrode. A redox shuttle in solution is employed to regenerate the dye. Diffusion of the oxidized form of the shuttle to the counter electrode completes the circuit. ${ }^{1,2}$ Scheme 1 shows a description of this photoelectrochemical Grätzel type cell. Regarding the redox shuttle or mediator, a key aspect to be considered is its redox potential that should permit a thermodynamically favored reduction of the dye, but at the same time posses a sufficiently high $\Delta \mathrm{V}$ value to permit the functioning of the cell. Ultimately, the optimum redox mediator for a given cell will depend on the nature and redox properties of the specific dye incorporated in it.

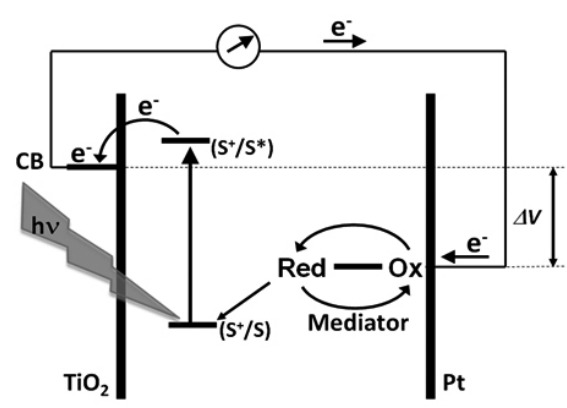

Scheme 1
Until now, the best efficiencies have been obtained with polypyridine $\mathrm{Ru}(\mathrm{II})$ dyes used in conjunction with $\mathrm{I}^{-} / \mathrm{I}_{3}^{-}$as mediator. As a mediator, $\mathrm{I}^{-} / \mathrm{I}_{3}^{-}$ seems to have ideal kinetic properties; ${ }^{4}$ specifically, the regeneration of the dye by $\mathrm{I}^{-}$is very fast, while the detrimental recombination of $\mathrm{I}_{3}^{-}$with photoinjected electrons in the $\mathrm{TiO}_{2}$ is a slow two electron transfer process. ${ }^{5}$ Nevertheless, regardless of these positive characteristics and its efficiency, alternatives to this shuttle should be considered, given first, its corrosive nature and volatility, that affects the durability of eventual commercial modules, ${ }^{6}$ and second, its absorption in the visible region, that competes with the absorption of the dye.

Alternative mediators, as one-electron outer sphere redox systems with rapid electron exchange kinetics such as ferrocene/ferricinium, give low photovoltages and low photocurrents as a consequence of rapid back reaction of photoinjected electrons with the oxidized redox component. ${ }^{5,8}$

Other outer-sphere one electron mediators, as Cobalt polypyridyl couples, have also been considered as alternative shuttles, ${ }^{7}$ because they are expected to have the capacity to satisfy the main requirements these redox mediators should have, as efficient reduction of the dye with minimal overpotential, fast reduction at the cathode, slow interception of electrons contained in the photoanode, nonvolatility, and little light absorption in the spectral region where de dye absorbs, both in oxidized and reduced form. ${ }^{6}$ The slower rate of interaction with electrons in the photoanode for the Co polypyridyl couples when compared to the ferrocene/ferrocinium couple arises mainly from the change in spin multiplicity involved in the former. ${ }^{4}$ On the other hand, when compared to the iodine couple, that possesses a sole redox potential, the possibility to tune the redox potential by changes in the ligand electronic properties appears as an additional advantage of Cobalt polypiridine type complexes.

Although very promising results were reported for the cobalt based redox mediator $\mathrm{Co}(\mathrm{II})(\mathrm{dbbip})_{2}\left(\mathrm{ClO}_{4}\right)_{2}$, with dbbip = 2,6-bis(1'-butylbenzimidazol$2^{\prime}$-yl)pyridine), ${ }^{7 \mathrm{~d}, \mathrm{e}}$ other parent systems of the type $\mathrm{Co}(\mathrm{II})(\mathrm{LL})_{3}{ }^{2+3+}$, with LL = bpy, phen and substituted derivatives, have shown very low efficiency. Factors as slow diffusion and reduction of the Co(III) form of the mediator at the photoanode, have been discussed, among other variables, as the possible reasons for this rather low response. Ultrathin coating of the nanoparticulated $\mathrm{TiO}_{2}$ with alumina has been tested as a protection to prevent the deactivation of the photogenerated electrons by the oxidized form of the redox mediator. ${ }^{\text {a }}$

In this work a series of polypyridine Cobalt(II) and Cobalt(III) complexes of the type $\left[\mathrm{Co}(\mathrm{L}-\mathrm{L})_{3}\right]^{\mathrm{n}+}$ with $\mathrm{L}-\mathrm{L}=1,10$-phenanthroline (phen), 5-amino1,10'-phenanthroline (phen- $\mathrm{NH}_{2}$ ), 3,4,7,8-tatramethyl phenantroline (phen$4 \mathrm{Me})$, pyrazino[2,3-f][1,10]phenanthroline (ppl), 2-methylpyrazino[2,3-f] $[1,10]$ phenanthroline (ppl-Me), dipyrido[3,2-a:2',3'-c]phenazine (dppz), 7-methyldipyrido[3,2-a:2',3'-c]phenazine (dppz-Me) and 
7-aminodipyrido[3,2-a:2', $\left.3^{\prime}-c\right]$ phenazine $\left(\mathrm{dppz}-\mathrm{NH}_{2}\right)$, were synthesized and systematically studied, mainly from a spectroscopic and electrochemical point of view. Differentiating from previous literature reports in this area, where the Co(III) species are generated in situ, in this work the Co(III) species were isolated as a solid, to permit its characterization, and a better control of the $\mathrm{Co}(\mathrm{II}) / \mathrm{Co}(\mathrm{III})$ concentration relation. The effect on the redox potential of the $\mathrm{Co}(\mathrm{II} / \mathrm{III})$ couple of the presence of donor or acceptor substituents on the ligand, as well as the effect of an increased ligand aromaticity, was analyzed. The results of this study open the possibility to choose as alternative redox mediator - for a specific cell and according to the dye properties - some of the Co(II)/ $\mathrm{Co}$ (III) couples here reported, especially in cases where the regeneration of the dye by the traditionally used iodine based mediator, is thermodynamically unattainable.

\section{Experimental Section}

Materials. Solvents were of ACS grade. All reagents and solvents were used as received. 1,10-phenantroline (phen) and 3,4,7,8-tatramethyl phenantroline (phen-4Me) were obtained from Aldrich.

\section{Analytical methods}

UV-Vis and Emission Spectroscopy. UV-Vis absorbance measurements were made on a Shimadzu UV 3101PC spectrophotometer.

Infrared Spectra. Infrared (IR) spectra for the desired compounds and reactants were recorded as $\mathrm{KBr}$ mulls in a Bruker Vector $22 \mathrm{FTIR}$ spectrometer.

Analytical Data: Elemental Analysis were performed on a Fisons Instrument Analyzer, model EA1108/CHNS-O with PC NCR system 3225, while Mass Spectra were recorded with an LCQ Duo Ion Trap Mass Spectrometer (Thermo Finnigan, USA).

NMR. ${ }^{1} \mathrm{H}-\mathrm{NMR}$ spectra were recorded on a Bruker ACL $200200 \mathrm{MHz}$ spectrometer with TMS as reference or on a Bruker AVANCE 400 FT-NMR spectrometer.

Electrochemistry. Cyclic Voltammograms were taken in dry $\mathrm{CH}_{3} \mathrm{CN}$ nitrogen saturated $1 \times 10^{-3} \mathrm{M}$ solutions of the corresponding complex, at 100 $\mathrm{mV} / \mathrm{s}$ sweep rate, with $0.1 \mathrm{M}$ tetrabutylammonium hexafluorophosphate (TBAH) as supporting electrolyte. A BAS model CV50w potentiostat was used in a standard three-electrode arrangement with a Pt or glassy platinum working electrode, a Pt gauze counter electrode, and a $\mathrm{Ag} / \mathrm{Ag}^{+} \mathrm{AgNO}_{3} 0.01 \mathrm{M}$ reference electrode. The measured $\mathrm{E}_{1 / 2}$ values were adjusted to be referred $\mathrm{v} / \mathrm{s}$ NHE.

\section{Synthesis}

Co(II) complexes:

All the Co(II) complexes were synthesized in a similar way as described by Shawn A. Sapp. ${ }^{7 b}$ A solution of three equivalents of the corresponding ligand was dissolved in methanol with magnetic stirring, and the solution taken to reflux temperature until ligand dissolution. One equivalent of $\mathrm{CoCl}_{2} 5 \mathrm{xH}_{2} \mathrm{O}$ in methanol was then added. The mixture was refluxed for 2 hours and then cooled to room temperature. The total volume was reduced to $c a 70 \%$ with the use of rotary evaporation. Addition of $\mathrm{NH}_{4} \mathrm{PF}_{6}$ and ethyl ether caused the precipitation of the desired complex, which was finally filtered and washed with diethyl ether

$\left[\mathrm{Co}(\mathrm{phen})_{3}\right](\mathrm{PF})_{2}$. Yield (85\%). IR, $\mathrm{KBr}\left(\mathrm{cm}^{-1}\right) v_{\mathrm{p} F}=834,557$. Anal $\mathrm{C}_{36} \mathrm{H}_{24} \mathrm{~N}_{6} \mathrm{CoF}_{12} \mathrm{P}_{2}$ (\%) Cal.: C 48.61; H 2.72; N 9.45 Exp.: C 48.88; H 3.56; N 9.52 .

$\left[\mathrm{Co}\left(\text { phen- } \mathrm{NH}_{2}\right)_{3}\right]\left(\mathrm{PF}_{6}\right)_{2}$. Yield (93\%). IR, $\mathrm{KBr}\left(\mathrm{cm}^{-1}\right) v_{\mathrm{N}}=3223 ; \mathrm{n}_{\mathrm{p}}$ $\mathrm{F}_{\mathrm{F}}=842,558 . \mathrm{m} / \mathrm{Z} 468\left(\mathrm{M}^{+}-\mathrm{PF}_{6}^{-}\right) ; 322\left(\mathrm{M}+-2 \mathrm{PF}_{6}^{-}\right) ; 224\left(\mathrm{M}+\left(\right.\right.$ phen- $\left.\left.\mathrm{NH}_{2}\right)-2 \mathrm{PF}_{6}^{-}\right)$

$\left[\mathrm{Co}(\right.$ phen-4Me) $](\mathrm{PF})$. Yield $(96 \%)$. IR, $\mathrm{KBr}\left(\mathrm{cm}^{-1}\right) v_{\mathrm{C}}=2927 ; \mathrm{n}_{\mathrm{p}}$ $=841,558$. Anal. $\mathrm{C}_{48} \mathrm{H}_{48} \mathrm{~N}_{6} \mathrm{CoF}_{12} \mathrm{P}_{2}(\%) \mathrm{Cal} . \mathrm{C} 54.50 ; \mathrm{H} 4.57 ; \mathrm{N}$ 7.94. Exp.: C 54.35; H 4.87; N 7.89 .

$\left[\mathrm{Co}(\mathrm{ppl})_{3}\right]\left(\mathrm{PF}_{6}\right)_{2}$. Yield $(62 \%)$. IR, $\mathrm{KBr}\left(\mathrm{cm}^{-1}\right) v_{\mathrm{P}-\mathrm{F}}=840$, 557. Anal. $\mathrm{C}_{42} \mathrm{H}_{24} \mathrm{~N}_{12} \mathrm{CoF}_{12} \mathrm{P}_{2}$ (\%) Cal.: C 48.25; H 2.31; N 16.08 Exp.: C 48.56; H 3.04; $\mathrm{N} 16.01$.

$\left[\mathrm{Co}(\mathrm{ppl}-\mathrm{Me})_{3}\right]\left(\mathrm{PF}_{6}\right)_{2}$. Yield $(86 \%)$. IR, $\mathrm{KBr}\left(\mathrm{cm}^{-1}\right) v_{\mathrm{C}}$, $2926 ; \mathrm{n}_{\mathrm{P} F \mathrm{~F}}=$ 841, 557. Anal. $\mathrm{C}_{45} \mathrm{H}_{30} \mathrm{~N}_{12} \mathrm{CoF}_{12} \mathrm{P}_{2}$ (\%) Cal.: C 49.69; H 2.87; N 15.45 Exp.: $\mathrm{C}$ 49.38; H 3.05; N 15.34 .

$\left[\mathrm{Co}(\mathrm{dppz})_{3}\right]\left(\mathrm{PF}_{6}\right)_{2}$. Yield (57\%). IR, $\mathrm{KBr}\left(\mathrm{cm}^{-1}\right) v_{\mathrm{P} \mathrm{F}}=848$, 558. Anal. $\mathrm{C}_{54} \mathrm{H}_{30} \mathrm{~N}_{12} \mathrm{CoF}_{12} \mathrm{P}_{2}(\%)$ Cal.: $\mathrm{C}$ 54.24; H 2.53; N 14.06 Exp.: C 53.98; H 2.78; $\mathrm{N} 13.97$.

$\left[\mathrm{Co}(\mathrm{dppz}-\mathrm{Me})_{3}\right]\left(\mathrm{PF}_{6}\right)_{2}$. Yield (53\%). IR, $\mathrm{KBr}\left(\mathrm{cm}^{-1}\right) v_{\mathrm{C}-\mathrm{H} \text { Alifatic }}=2930 ; \mathrm{n}_{\mathrm{P}}$ $=840,558$. Anal. $\mathrm{C}_{57} \mathrm{H}_{36} \mathrm{~N}_{12} \mathrm{CoF}_{12} \mathrm{P}_{2}(\%)$ Cal.: C 55.31; $\mathrm{H} 2.93 ; \mathrm{N} 13.58$ Exp. C 55.09; H 3.14; N 13.37 .

$\left[\mathrm{Co}\left(\mathrm{dppz}-\mathrm{NH}_{2}\right)_{3}\right]\left(\mathrm{PF}_{6}\right)_{2}$. Yield $(66 \%)$. IR, $\mathrm{KBr}\left(\mathrm{cm}^{-1}\right) v_{\mathrm{N}}$. $=833,559$. Anal. $\mathrm{C}_{54} \mathrm{H}_{33} \mathrm{~N}_{15} \mathrm{CoF}_{12} \mathrm{P}_{2}(\%)$ Cal.: C 52.27; H 2.68; N 16.93 Exp.: C 52.49; H 2.98; N 17.09

\section{Co(III) Complexes:}

The oxidation of the corresponding Co(II) complex was done by the addition of an equivalent amount of nitrosonium tetrafluoroborate $\left(\mathrm{NOBF}_{4}\right)$ in an acetonitrile solution. This mixture was stirred for 1 hour. The total volume was reduced to $\mathrm{ca} 70 \%$ with the use of rotary evaporation. Addition of $\mathrm{NH}_{4} \mathrm{PF}_{6}$ and ethyl ether caused the precipitation of the corresponding complex, although in some of them precipitation occurred with $\mathrm{BF}_{4}^{-}$as counter ion. The presence of $\mathrm{BF}_{4}^{-}$or $\mathrm{PF}_{6}^{-}$as counterion was elucidated by IR. For $\mathrm{Co}(\mathrm{II})$ complexes with $\mathrm{NH}_{2}$ substituents, the oxidation was performed bubbling air for 6 hour.

$\left[\mathrm{Co}(\mathrm{phen})_{3}\right]\left(\mathrm{BF}_{4}\right)_{3}$. Yield $(80 \%)$. IR, $\mathrm{KBr}\left(\mathrm{cm}^{-1}\right) \mathrm{v}_{\mathrm{B}-\mathrm{F}}=1083,1055,1034$. $\left.{ }^{1} \mathrm{H}-\mathrm{NMR}\left(\mathrm{CD}_{3}\right)_{2} \mathrm{CO}\right) \delta(\mathrm{ppm}) 9.00(\mathrm{dd}, 6 \mathrm{H}, \mathrm{H1}), 8.45$ (s, 6H, H4), 7.88 (dd, 6H, $\mathrm{H} 2), 7.50(\mathrm{~d}, 6 \mathrm{H}, 3 \mathrm{H})$. Anal. $\mathrm{C}_{36} \mathrm{H}_{24} \mathrm{~N}_{6} \mathrm{CoF}_{12} \mathrm{~B}_{3}(\%) \mathrm{Cal}$. $\mathrm{C} 50.28 ; \mathrm{H} 2.81 ; \mathrm{N}$ 9.77 Exp.: C $50.49 ; \mathrm{H} 2.98$; $\mathrm{N} 9.85$

$\left[\mathrm{Co}\left(\text { phen- } \mathrm{NH}_{2}\right)_{3}\right]\left(\mathrm{PF}_{6}\right)_{3}$. Yield (75\%). IR, $\mathrm{KBr}\left(\mathrm{cm}^{-1}\right) v_{\mathrm{N}-\mathrm{H} \text { Alifatic }}=3229 ; v_{\mathrm{P}}$ $=840,557 .{ }^{1} \mathrm{H}-\mathrm{NMR}\left(\mathrm{CD}_{3} \mathrm{CN}\right) \delta(\mathrm{ppm}) 8.99(\mathrm{dd}, 3 \mathrm{H}, \mathrm{H1}), 8.56$ (dd, 3H, H1'), 7.93-7.81 (m, 3H, H3), 7.66-7.42 (m, 6H, H3', H2), 7.32 (s, 3H, H4), 7.19-7.02 (m, 3H, H2'), $5.94\left(\mathrm{~s}, 6 \mathrm{H}, \mathrm{NH}_{2}\right)$. Anal. $\mathrm{C}_{36} \mathrm{H}_{27} \mathrm{~N}_{9} \mathrm{CoF}_{18} \mathrm{P}_{3}(\%)$ Cal.: $\mathrm{C} 40.05 ; \mathrm{H}$ 2.52; N 11.68 Exp.: C 40.23; H 2.59; N 11.79

$\left[\mathrm{Co}(\text { phen-4Me })_{3}\right]\left(\mathrm{BF}_{4}\right)_{3}$. Yield $(96 \%) . \mathrm{IR}, \mathrm{KBr}\left(\mathrm{cm}^{-1}\right) v_{\mathrm{C}-\mathrm{H} \text { Alifatic }}=2930$; $v_{\mathrm{B}-\mathrm{F}}=1083,1055,1036 .{ }^{1} \mathrm{H}-\mathrm{NMR}\left(\mathrm{CD}_{3} \mathrm{CN}\right) \delta(\mathrm{ppm}) 8.48(\mathrm{~s}, 6 \mathrm{H}, \mathrm{H1}), 7.01(\mathrm{~s}$, $6 \mathrm{H}, \mathrm{H} 4), 2.86\left(\mathrm{~s}, 18 \mathrm{H}, \mathrm{CH}_{3}\right), 2.27\left(\mathrm{~s}, 18 \mathrm{H}, \mathrm{CH}_{3}\right)$. Anal. $\mathrm{C}_{48} \mathrm{H}_{48} \mathrm{~N}_{6} \mathrm{CoF}_{12} \mathrm{~B}_{3}(\%)$ Cal.: C 56.07; H 4.71; N 8.17 Exp.: C 56.43; H 4.79; N 8.26

$\left[\mathrm{Co}(\mathrm{ppl})_{3}\right]\left(\mathrm{BF}_{4}\right)_{3}$. Yield $(85 \%)$. IR, $\mathrm{KBr}\left(\mathrm{cm}^{-1}\right) v_{\mathrm{B}-\mathrm{F}}=1083,1055,1033$. ${ }^{1} \mathrm{H}-\mathrm{NMR}\left(\mathrm{CD}_{3} \mathrm{CN}\right) \delta(\mathrm{ppm}) 9.88$ (dd, 6H, H1), 9.36 (s, 6H, H4), 8.08 (dd, 6H, $\mathrm{H} 2$ ), 7.78 (dd, $6 \mathrm{H}, \mathrm{H} 1$ ). Anal. $\mathrm{C}_{42} \mathrm{H}_{24} \mathrm{~N}_{12} \mathrm{CoF}_{12} \mathrm{~B}_{3}$ (\%) Cal.: C 49.65; H 2.38; N 16.54 Exp.: C 49.93; H 2.41; N 16.71

$\left[\mathrm{Co}(\mathrm{ppl}-\mathrm{Me})_{3}\right]\left(\mathrm{BF}_{4}\right)_{3}$. Yield $(82 \%)$. IR, $\mathrm{KBr}\left(\mathrm{cm}^{-1}\right) v_{\mathrm{C}}=2923 ; v_{\mathrm{B}}=$ $1083,1061,1033$. 'H-NMR (CD $\left.{ }_{3} \mathrm{CN}\right) \delta(\mathrm{ppm}) 9.90-9.82(\mathrm{~m}, 6 \mathrm{H}, \mathrm{H} 3 \mathrm{H} 3$ ') $), 9.23$ (s, 3H, H4), 8.12-8.03 (m, 6H, H2 H2'), 7.80-7.75 (m, 6H, H1 H1'), 2.98 (s, 9H, $\left.\mathrm{CH}_{3}\right)$. Anal. $\mathrm{C}_{45} \mathrm{H}_{30} \mathrm{~N}_{12} \mathrm{CoF}_{12} \mathrm{~B}_{3}(\%)$ Cal.: C 51.08; H 2.86; N 15.88 Exp.: C 51.53; H 2.90; N 15.97

$\left[\mathrm{Co}(\mathrm{dppz})_{3}\right]\left(\mathrm{BF}_{4}\right)_{3}$. Yield (51\%). IR, $\mathrm{KBr}\left(\mathrm{cm}^{-1}\right) \mathrm{v}_{\mathrm{B}-\mathrm{F}}=1083,1054,1034$. ${ }^{1} \mathrm{H}-\mathrm{NMR}\left(\left(\mathrm{CD}_{3}\right)_{2} \mathrm{SO}\right) \delta$ (ppm) 9.97 (d, 6H, H3), 8.61-8.59 (m, 6H, H4), 8.308.27 (m, 6H, H5), 8.22-8.17 (m, 6H, H2), 7.95-7.93 (m, 6H, H1). Anal. $\mathrm{C}_{54} \mathrm{H}_{30} \mathrm{~N}_{12} \mathrm{CoF}_{12} \mathrm{~B}_{3}$ (\%) Cal.: C 55.61; H 2.59; N 14.41 Exp.: C 56.02; H 2.62; $\mathrm{N} 14.52$

$\left[\mathrm{Co}(\mathrm{dppz}-\mathrm{Me})_{3}\right]\left(\mathrm{BF}_{4}\right)_{3}$. Yield $(52 \%) . \mathrm{IR}, \mathrm{KBr}\left(\mathrm{cm}^{-1}\right) v_{\mathrm{B}-\mathrm{F}}=1083,1055$, 1033. ${ }^{1} \mathrm{H}-\mathrm{NMR}\left(\left(\mathrm{CD}_{3}\right)_{2} \mathrm{SO}\right) \delta(\mathrm{ppm}) 9.93\left(\mathrm{~d}, 6 \mathrm{H}, \mathrm{H3} \mathrm{H3}{ }^{\prime}\right), 8.49$ (s, 3H, H4), 8.37 (s, 3H, H4'), 8.20-8.15 (m, 6H, H2 H2'), 8.12 (d, 3H, H5), 7.93 (d, 6H, H1 H1'), 2.76 (s, $9 \mathrm{H}, \mathrm{CH}_{3}$ ). Anal. $\mathrm{C}_{58} \mathrm{H}_{40} \mathrm{~N}_{12} \mathrm{CoF}_{12} \mathrm{~B}_{3}(\%) \mathrm{Cal}$.: C 56.90; H 3.29; N 13.73 Exp.: C 57.22; H 3.35; N 13.81

$\left[\mathrm{Co}\left(\mathrm{dppz}-\mathrm{NH}_{2}\right)_{3}\right]\left(\mathrm{PF}_{6}\right)_{3}$. Yield $(50 \%)$. IR, $\mathrm{KBr}\left(\mathrm{cm}^{-1}\right) v_{\mathrm{N}}=3330$; $3204 v_{\mathrm{p}}=835,559 .{ }^{1} \mathrm{H}-\mathrm{NMR}\left(\left(\mathrm{CD}_{3}\right)_{2} \mathrm{SO}\right) \delta(\mathrm{ppm}) 9.53(\mathrm{~d}, 3 \mathrm{H}, \mathrm{H} 3), 9.45(\mathrm{~d}$, $3 \mathrm{H}, \mathrm{H}^{\mathrm{p}}$ '), 9.18 (d, 3H, H1), 9.12 (d, 3H, H1'), 8.05 (s, 3H, H4), 7.96-7.91 (m, $\left.6 \mathrm{H}, \mathrm{H} 2 \mathrm{H} 2^{\prime}\right), 7.50$ (d, 3H, H5), 7.13 (s, 3H, H4'). Anal. $\mathrm{C}_{54} \mathrm{H}_{33} \mathrm{~N}_{9} \mathrm{CoF}_{18} \mathrm{P}_{3}(\%)$ Cal.: C 46.80; H 2.40; N 15.16 Exp.: C 47.06; H 2.44; N 15.28

\section{Characterization}

The synthesis of the $\mathrm{Co}(\mathrm{II})$ and $\mathrm{Co}(\mathrm{III})$ complexes described in this work was attained with reasonable good yields, over $50 \%$. The microanalytical results were in satisfactory agreement with the predicted values for the corresponding tris homoleptic complexes. The $\left[\mathrm{Co}\left(\text { phen- } \mathrm{NH}_{2}\right)_{3}\right]\left(\mathrm{PF}_{6}\right)_{2}$ complex was additionally characterized by Mass Spectroscopy. The IR spectra of the series of cationic complexes under study showed the presence of the $\mathrm{PF}_{6}-$ bands at 840 and $558 \mathrm{~cm}^{-1}$. For compounds $\left[\mathrm{Co}\left(\mathrm{phen}-\mathrm{NH}_{2}\right)_{3}\right]\left(\mathrm{PF}_{6}\right)_{2}$ and $\left[\mathrm{Co}\left(\mathrm{dppz}-\mathrm{NH}_{2}\right)\right](\mathrm{PF})$, bands assignable to the $\mathrm{NH}_{2}$ groups at 3223 and 3210 $\mathrm{cm}^{-1}$ are also observed, while for complexes $\left[\mathrm{Co}(\text { phen-4Me })_{3}\right]\left(\mathrm{PF}_{6}\right)_{2}$, [Co(ppl$\left.\mathrm{Me})_{3}\right]\left(\mathrm{PF}_{6}\right)_{2}$ and $\left[\mathrm{Co}(\mathrm{dppz}-\mathrm{Me})_{3}\right]\left(\mathrm{PF}_{6}\right)_{2}$, the corresponding methyl C-H signals at 2927,2926 y $2930 \mathrm{~cm}^{-1}$ are present. The ${ }^{1} \mathrm{H}$-NMR spectra for the Co(III) ${ }^{9}$ low spin complexes permit to unambiguously assure the presence of the corresponding tris homoleptic complex. As an example, Figure 1 shows the ${ }^{1} \mathrm{H}-\mathrm{NMR}$ spectrum for $\left[\mathrm{Co}\left(\text { phen- } \mathrm{NH}_{2}\right)_{3}\right]^{3+}$ in $\mathrm{CD}_{3} \mathrm{CN}$; the assignment of the signals is also shown. Given the paramagnetic nature of the $\mathrm{Co}$ (II) complexes, no ${ }^{1} \mathrm{H}-\mathrm{NMR}$ spectra is reported. 


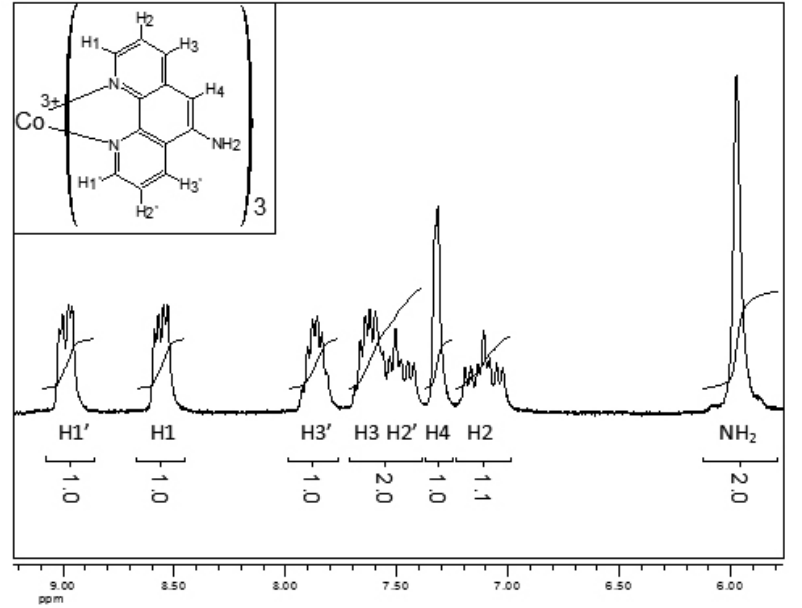

Figure 1. ${ }^{1} \mathrm{H}-\mathrm{NMR}$ spectrum for $\left[\mathrm{Co}\left(\text { phen- }-\mathrm{NH}_{2}\right)_{3}\right]^{3+}$ in $\mathrm{CD}_{3} \mathrm{CN}$. Proton numbering is shown in the inset.

\section{RESULTS AND DISCUSSION}

UV-Vis.

All the $\mathrm{Co}(\mathrm{II})$ and $\mathrm{Co}(\mathrm{III})$ complexes dissolved in acetonitrile show a common absorption pattern, with two distinct regions, one between 220 to $350 \mathrm{~nm}$ with high intensity absorption bands $\left(\varepsilon=90,000\right.$ to $240,000 \mathrm{M}^{-1} \mathrm{~cm}^{-}$ $\left.{ }^{1}\right)$ and a second lower intensity region, from 350 to $460 \mathrm{~nm}$ ( $\varepsilon=20,000$ to $40,000 \mathrm{M}^{-1} \mathrm{~cm}^{-1}$ ). Both can be assigned to ligand centered bands, mostly of $\pi-\pi^{*}$ origin. ${ }^{7 \mathrm{~b}}$ The main exception to this assignment appears in the case where $\mathrm{NH}_{2}$ appears as substituent in the ligand, where intraligand charge transfer bands are to be expected. Figure 2 shows the spectra corresponding to $\left[\mathrm{Co}(\mathrm{ppl}-\mathrm{Me})_{3}\right]^{2+}$ and $\left[\mathrm{Co}(\mathrm{ppl}-\mathrm{Me})_{3}\right]^{3+}$. When comparing the spectra of a given $\mathrm{Co}^{2+}$ complex with its analogue of $\mathrm{Co}^{3+}$, for example $\left[\mathrm{Co}(\mathrm{ppl}-\mathrm{Me})_{3}\right]^{2+}$ and $\left[\mathrm{Co}(\mathrm{ppl}-\mathrm{Me})_{3}\right]^{3+}$ in Figure 2 , a similar pattern is observed, with displacements of the banad maxima. For example, as shown in Table 1, $\left[\mathrm{Co}(\text { phen })_{3}\right]^{2+}$ presents absorption bands at 267 and $280 \mathrm{~nm}$, while for its oxidized equivalent, $\left[\mathrm{Co}(\mathrm{phen})_{3}\right]^{3+}$, these bands appear at 280 and $303 \mathrm{~nm}$. This effect can be ascribed to the stronger Lewis acid character of $\mathrm{Co}^{3+}$ in regard to $\mathrm{Co}^{2+}$, which would decrease the electron density on the $\pi$ type orbitals of the ligand.

When comparing complexes with the metal in the same oxidation state but with different ligands, the general trend is that the more aromatic ligands as ppl and dppz, tend to present bands at lower energy when compared to phen, as expected for the stabilization of their $\pi^{*}$ levels. Finally, the donor properties of substituents on the ligands, as in dppz-Me and dppz- $\mathrm{NH}_{2}$, compared to dppz, are also reflected in a displacement to the red, with bands at 280 and $316 \mathrm{~nm}$, respectively, for the formers, and at $268 \mathrm{~nm}$ for the latter.
It is relevant to point out that, with the sole exception of $\left[\mathrm{Co}\left(\mathrm{dppz}-\mathrm{NH}_{2}\right)_{3}\right]^{2+}$ that presents a band at $457 \mathrm{~nm}$ with e of $21,000 \mathrm{M}^{-1} \mathrm{~cm}^{-1}$, that can be assigned to an intraligand (IL) transition, ${ }^{15}$ the Cobalt complexes under study do not noticeably absorb in the visible region. In some cases, very low intensity ligand field bands can be observed. For example, for $\left[\mathrm{Co}(\mathrm{phen})_{3}\right]^{2+}$ these bands appear at bands at 440 and $930 \mathrm{~nm}$ of $\varepsilon=90$ and $10 \mathrm{M}^{-1} \mathrm{~cm}^{-1}$, respectively.

a)

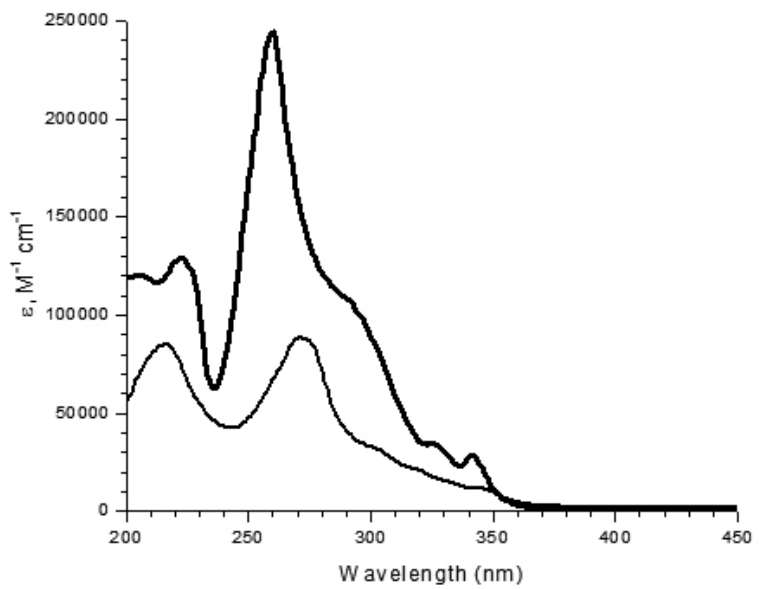

b)

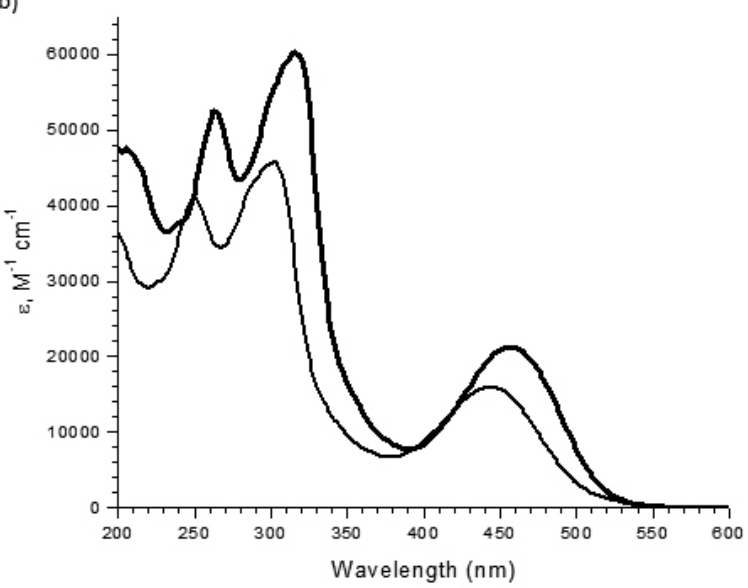

Figure 2. Absorption spectra in $\mathrm{CH}_{3} \mathrm{CN}$. (a) $\left[\mathrm{Co}(\mathrm{ppl}-\mathrm{Me})_{3}\right]^{2+}($ - $)$ and $\left[\mathrm{Co}(\mathrm{ppl}-\mathrm{Me})_{3}\right]^{3+}\left(\right.$ 一).(b) $\left[\mathrm{Co}\left(\mathrm{dppz}-\mathrm{NH}_{2}\right)_{3}\right]^{2+}(-)$ and $\left[\mathrm{Co}\left(\mathrm{dppz}-\mathrm{NH}_{2}\right)_{3}\right]^{3+}($ 一).

Table 1. Absorption spectra in $\mathrm{CH}_{3} \mathrm{CN}$ for the complexes $\left[\mathrm{Co}(\mathrm{L}-\mathrm{L})_{3}\right]^{2+}$ and $\left[\mathrm{Co}(\mathrm{L}-\mathrm{L})_{3}\right]^{3+}$

\begin{tabular}{|l|lll|lll|ll|ll|}
\hline \multicolumn{1}{|c|}{ L-L } & \multicolumn{5}{|c|}{$\left[\mathrm{Co}(\mathrm{L}-\mathrm{L})_{3}\right]^{2+} \mathbf{A b s}, \mathbf{n m}$} & \multicolumn{5}{c|}{$\left[\mathrm{Co}(\mathrm{L}-\mathrm{L})_{3}\right]^{3+}$ Abs ,nm } \\
\hline phen & 227 & 267 & $290(\mathrm{sh})$ & 346 & 220 & 280 & 303 & 348 \\
\hline phen-4Me & 240 & 274 & $310(\mathrm{sh})$ & $318(\mathrm{sh})$ & $333(\mathrm{sh})$ & 225 & 289 & 313 & $334(\mathrm{sh})$ & 352 \\
\hline phen-NH & 241 & 261 & 288 & 353 & $436(\mathrm{sh})$ & 241 & 261 & 290 & 355 \\
\hline ppl & 241 & 256 & 288 & $323(\mathrm{sh})$ & 339 & 268 & $299(\mathrm{sh})$ & $318(\mathrm{sh})$ & 340 \\
\hline ppl-Me & 222 & 260 & $293(\mathrm{sh})$ & $325(\mathrm{sh})$ & 342 & 216 & 272 & $302(\mathrm{sh})$ & $320(\mathrm{sh})$ & 345 \\
\hline dppz & $242(\mathrm{sh})$ & 268 & $291(\mathrm{sh})$ & 359 & 377 & 275 & 292 & $345(\mathrm{sh})$ & 377 \\
\hline dppz-Me & $228(\mathrm{sh})$ & 280 & $297(\mathrm{sh})$ & 364 & 384 & $232(\mathrm{sh})$ & 291 & 366 & 384 \\
\hline dppz-NH & 263 & 316 & $355(\mathrm{sh})$ & 457 & & 250 & 302 & 443 & \\
\hline
\end{tabular}

Electrochemical Properties

The redox properties of the Co(II) complexes under study were studied by cyclic voltammetry. As an example, Figure 3 shows the $\mathrm{CV}$ for [Co(phen-4Me) $]^{2+}$ and $\left[\mathrm{Co}(\mathrm{ppl}-\mathrm{Me})_{3}\right]^{2+}$ in $\mathrm{CH}_{3} \mathrm{CN}$. In Table 2 the half wave potentials vs. NHE for all the Co(II)/Co(III) redox couples is shown. The existence of reversible 
monoelectronic processes in all the cases was verified with an internal ferrocene standard. As should be expected, the redox potential of the different couples is sensible to the electronic nature of the substituent. Specifically, incorporation of donor groups to the polypyridinic ligands makes the metal oxidation easier. For example, $\mathrm{E}_{1 / 2}=638 \mathrm{mV}$ for $\left[\mathrm{Co}(\mathrm{phen})_{3}\right]^{2+/ 3+}$ while $\mathrm{E}_{1 / 2}=384$ $\mathrm{mV}$ for $\left[\mathrm{Co}(\text { phen- } 4 \mathrm{Me})_{3}\right]^{2+/ 3+}$. Conversely, an enhanced ligand aromaticity in regard to phen, as in ppl and dppz, reflects in a more difficult oxidation process in the corresponding complexes, showing the electronic acceptor nature of this type of ligands. ${ }^{11}$

Table 2. Electrochemical properties of Cobalt $\left[\mathrm{Co}(\mathrm{L}-\mathrm{L})_{3}\right]^{2+}$ type complexes.

\begin{tabular}{|l|c|c|c|}
\hline \multicolumn{1}{|c|}{$\mathbf{L}$} & $\mathbf{E}_{1 / 2}, \mathbf{m} \mathbf{V}^{a}$ & $\Delta \mathbf{E}, \mathbf{m V}$ & $\mathbf{E}_{\mathbf{p a}}\left(\mathbf{N H}_{\mathbf{2}}\right), \mathbf{m V}$ \\
\hline phen & 638 & 162 & --- \\
\hline phen-4Me & 384 & 78 & --- \\
\hline phen-NH & \\
\hline ppl & 494 & 90 & 1803 \\
\hline ppl-Me & 758 & 121 & --- \\
\hline dppz & 740 & 124 & --- \\
\hline dppz-NH & 754 & 60 & --- \\
\hline
\end{tabular}

${ }^{a} \mathrm{E}_{1 / 2}=1 / 2\left(E_{\mathrm{pa}}+E_{\mathrm{pc}}\right) \mathrm{v} / \mathrm{s}$ NHE for the $\mathrm{Co}(\mathrm{II} / \mathrm{III})$ process.
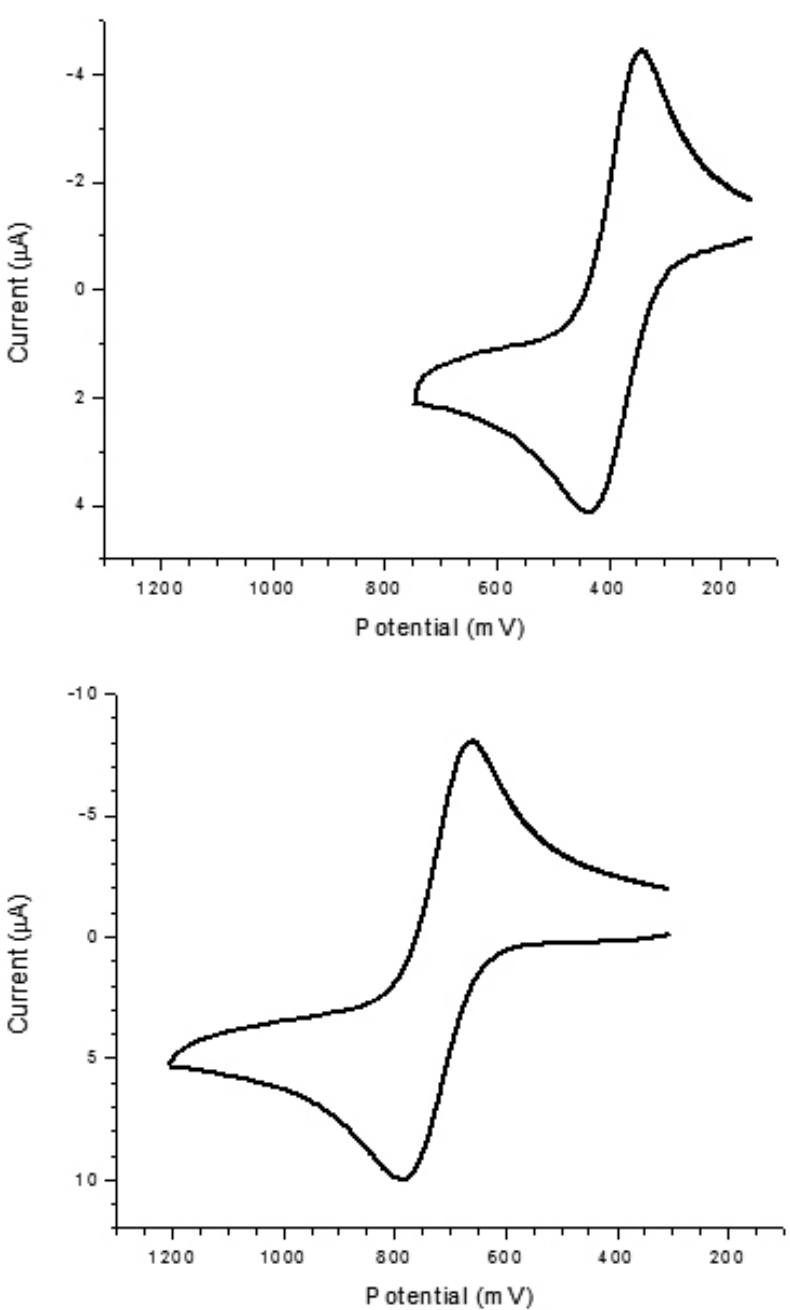

Figure 3. Cyclic voltammograms for: a) $\left[\mathrm{Co}(\text { phen-4Me })_{3}\right]^{2+}$ and b) $\left[\mathrm{Co}(\mathrm{ppl}-\mathrm{Me})_{3}\right]^{2+}$ in $\mathrm{CH}_{3} \mathrm{CN}$. The concentration of the complexes was $10^{-4} \mathrm{M}$, scan rate $100 \mathrm{mV} \mathrm{s}^{-1}$ and NHE as reference electrode.
Figure 4 shows the redox potentials for the different complexes, compared to other known redox couples. As can be seen, the series of Co couples offer potentials in the 0.38 to $0.75 \mathrm{~V}$ range, permitting to select the most suitable for a specific dye in a given cell, according to the potential needed for its regeneration. This permits alternatives to iodine, specially in cases where the potential of the latter, $(0.93 \mathrm{~V}),{ }^{14}$ may not be suitable to regenerate the dye, e.g., for cyclometallated $\mathrm{Ru}$ complexes, with $\mathrm{Ru}(\mathrm{II} / \mathrm{III})$ redox potentials of the order of $0.5-0.6 \mathrm{~V} .{ }^{16}$ According to Figure 4, and given the donor nature of its substituents, the $\left[\mathrm{Co}(\text { phen }-4 \mathrm{Me})_{3}\right]^{3+} /\left[\mathrm{Co}(\text { phen- } 4 \mathrm{Me})_{3}\right]^{2+}$ and $[\mathrm{Co}($ phen$\left.\left.\mathrm{NH}_{2}\right)_{3}\right]^{3+} /\left[\mathrm{Co}\left(\text { phen- }-\mathrm{NH}_{2}\right)_{3}\right]^{2+}$ couples seem to be the best candidates to replace iodine in these cases. Finally, the visible absorption observed in the case of where $\mathrm{NH}_{2}$ substituents are present, makes the $\left[\mathrm{Co}(\text { phen- } 4 \mathrm{Me})_{3}\right]^{3+} /[\mathrm{Co}($ phen$\left.4 \mathrm{Me})_{3}\right]^{2+}$ to be the best choice for the cases where the iodine potential is not sufficient for the dye regeneration.

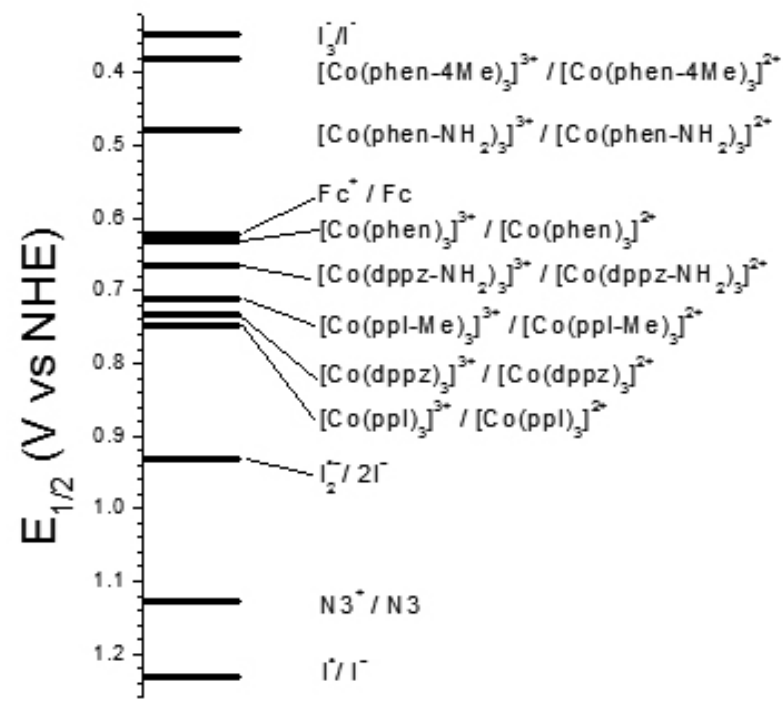

Figure 4: Electrochemical redox potentials $v s$. NHE for a series of Cobalt polypyridine couples of general type $\left[\mathrm{Co}(\mathrm{L}-\mathrm{L})_{3}\right]^{3+} /\left[\mathrm{Co}(\mathrm{L}-\mathrm{L})_{3}\right]^{2+}$. Values for $\mathrm{Fc} /$ $\mathrm{Fc}^{+}$and the iodine mediator are included for comparison reasons.

\section{CONCLUSION}

The use of varied polypyridinic ligands to synthesize different Co(II) tris homoleptic complexes has permitted to obtain compounds with an ample range of $\mathrm{Co}(\mathrm{II}) / \mathrm{Co}$ (III) redox potentials, and that at the same time are transparent in the visible region. As mentioned in the introduction, this is a necessary condition if these systems are intended to be used as mediators in solar cells, as this is the region where the dye usually absorbs, through MLCT bands, which are efficient for the light to electricity conversion in the cell. ${ }^{10}$ In the case of the $\left[\mathrm{Co}\left(\mathrm{dppz}-\mathrm{NH}_{2}\right)_{3}\right]^{2+/ 3+}$ couple, given that the reduced form absorbs in the visible region, its use as redox shuttle is less recommendable. The work here reported opens the possibility to have a battery of potential mediators for photoelectrochemical solar cells. Ultimately, the election of a determined couple as mediator will depend mainly on the electronic properties of the specific dye in a given cell.

\section{ACKNOWLEDGMENT}

FONDECYT Post doctorate Grant 3090026 (F.G.) is gratefully acknowledged.

\section{REFERENCES}

1). a). J. W. Ondersma, T. W. Hamann, J. Phys. Chem. C, 114, 638, (2010) b). J. C. Bernède, J. Chil. Chem. Soc. 53, 1549, (2008)

2). a). W. D. K. Clark, N. Sutin, J. Am. Chem. Soc., 99, 4676, (1977)

b). S. Anderson, E. C. Constable, M. P. Dare-Edwards, J. B. Hamnet, K. R. Seddon, R. D. Wright, Nature, 280, 571, (1979) 
3). a). B. O'Regan, M. Gratzel, Nature 353, 737, (1991)

b) M. K. Nazeruddin, A. Kay, I. Rodicio, R. Humphry-Baker, E. Müller, P. Liska, N. Vlachopoulos, M. Graetzel, J. Am. Chem. Soc., 115, 6382, (1993)

4). S. Cazzanti, S. Caramori, R. Argazzi, C. M. Elliott, C. A. Bignozzi, J. Am. Chem. Soc., 128, 9996, (2006)

5). P. J. Cameron, L. M. Peter, S. M. Zakeeruddin, M. Graetzel, Coordination Chemistry Reviews, 248, 1447, (2004)

6). a). M. J. DeVries, M. J. Pellin, J. T. Hupp, Langmuir, 26, 9082, (2010) b). W. Cheuquepán, D. Villagra, M. I. Azócar, G. Ramírez, Y. Y. Chen, B. Matsuhiro, L. Mendoza1, M. Isaacs, M. J. Aguirre, J. Chil. Chem. Soc, $\mathbf{5 5}, 254,(2010)$

c). C. San Martín, P. Dreyse, C. García, K. Alfumán, D. Villagra, M. Isaacs, J. Chil. Chem. Soc, 52, 1305, (2007)

7). a). B. M. Klahr, T. W. Hamann, J. Phys. Chem. C, 113, 14040, (2009)

b). S. A. Sapp, C. M. Eliott, C. Contado, S. Caramori, C. A. Bignozzi, J. Am. Chem. Soc., 124, 11215, (2002)

c). S. Nakade, Y. Makimoto, W. Kubo, T. Kitamura, Y. Wada, S. Yanagida, J. Phys. Chem. B, 109, 3488, (2005)

d). H. Nusbaumer, J-E. Moser, S. M. Zakeeruddin, K. Nazeeruddin, M. Graetzel, J. Phys. Chem. B, 105, 10461, (2001)

e). H. Nusbaumer, S. M. Zakeeruddin, J-E. Moser, M. Graetzel, Chem. Eur. J., 9, 3756, (2003)
8). B. A. Gregg, F. Pichot, S. Ferrere, C. L. Fields, J. Phys. Chem. B, 105, $1422,(2001)$

9). M. Ghosh, P. Biswas, U. Flörke, Polyhedron 26, 3750, (2007)

10). C. S. Karthikeyan, K. Peter, H, Wietasch, M. Thelakkat, Solar Energy Materials \& Solar Cells,91, 432, (2007)

11). a) M. Arias, J. Concepción, I. Crivelli, A. Delgadillo, R. Dıáz, A. Francois, F. Gajardo, R. López, A. M. Leiva, B. Loeb, Chemical Physics 326, 54, (2006)

b) A. Delgadillo, P. Romo, A. M. Leiva, B. Loeb, Helvetica Chimica Acta 86, 2110, (2003)

12). S. Ardo, G. J. Meyer, Chem. Soc. Rev. 38, 115, (2009)

13). N. S. Lewis, Inorg. Chem. 44, 6900, (2005)

14). J.G.Rowley, B.H. Farnum, Sh. Ardo, G. J. Meyer, J. Phys. Chem. Lett, 1 , 3132, (2010)

15). D. M. Cleland, G. Irwin, P. Wagner, D.L Officer, K.C. Gordon, Chem. Eur. J., 15, 3682, (2009)

16). M. Arias, Tesis para optar al grado de Doctor en Química, P. Universidad Católica de Chile, (2007) 